\title{
The effect of 5-aminolevulinic-acid (ALA) on the development of Saintpaulia ionantha
}

\author{
Tilly-Mándy, A., Honfi, P., Stefanovits-Bányai É., Mosonyi I.D., Köbli V. \& Hrotkó K. \\ Corvinus University of Budapest, Faculty of Horticultural Sciences, 29-43. Villányi út, Budapest, H-1118
}

\begin{abstract}
Summary: In recent work the effect of 5-aminolevulinic-acid (ALA) agent (commercial name Pentakeep-V) was examined on the chlorophyll content, growth and development of Saintpaulia ionantha. The newly re-rooted potted plants were irrigated or sprayed with $0.3 \%$ or $0.5 \%$ Pentakeep-V solution, and plus $30 \%$ long lasting fertilizer was added to half of the all treatments. Control plants were sprayed with tap water. Best result were obtained on the field of flowering. All the treatments promoted chlorophyll-content in the leaves especially spraying with $0.3 \%$ o concentration. Plants treated with Pentakeep-V in both concentrations and independently from the spraying or irrigation flowered more than two weeks earlier than control and those that got plus $30 \%$ fertilizer. Besides in the case of some treatments the diameter of leaf rosette, the number and surface size of leaves grew comparing to the control. The longlasting fertilizer had positive effect on the fresh weight but none of treatments had effect on the dry weight.
\end{abstract}

Key words: 5-aminolevulinic acid, chlorophyll content, leaf surface, leaf number, Pentakeep-V, Saintpaulia ionantha, flowering

\section{Introduction}

Saintpaulia ionantha is a common, cheep flowering pot plant, can be cultivated all the year. It doesn't react to daylength, the length of cultivation is 7 to 9 months depending on the variety Hamrick, 2003). The growing technology is worked out completely. In shortening the culture time and raising the quality of the product the application of biostimulators can bring further results.

Pentakeep-V is a newly developed crop promoter, conditioning fertilizer. Its agent is 5-amino-levulic-acid (ALA), one precursor of chlorophyll (Kosáry, 2008; Vágújfalvi, 2007). In Japan since 2000 research is going on, in Hungary it is introduced as plant fertilizer. Hotta et al. (1997) pointed out that ALA promoted the growth and yield of several crops and vegetables. ALA promoted photosynthesis with additional nutrients. The promotion by ALA was not proportional among chlorophyll content, chlorophyll concentration and fresh weight. In 1997 Hotta et al. reported that ALA in several concentrations increased $\mathrm{CO}_{2}$ fixation in light and decreased it in darkness. Bingshan et al. (1998) proved that ALA increased chlorophyll synthesis and fixation of $\mathrm{CO}_{2}$ in low concentrations by some vegetables. In 2000 Watanable et al. reported that ALA improved salt tolerance of cotton seedlings. Nishihara et al., (2003) found that ALA increased the $\mathrm{NaCl}$ tolerance of Spinacia oleracea plants. In 2006 Murányi made experiments with Pentakeep-V on tomato, paprika, sunflower and grape. Treating maize and sorghum Pásztor (2008) obtained better crop production and increased yield safety by both species. In Japan in 2001 Cosmo Seiwa Agriculture Co., Ltd. made research on pot Primula 'Julian Scarlett' cultivar. They used $0.02 \%$ concentration, every 6 th day and found that the cultivation period shortened considerably. Comparing to the control plants could be transferred to the flowermarket 20 days earlier. In 2004/2005 Yoshida et al. (2005) examined the effect of Pentakeep-V on bulb production of Tulipa 'Leen van der Mark' and 'Ballerina' cultivars. Treatments increased the number and size of bulbs by both varieties comparing to the control. Nowak in 2006 treated Chrysanthemum $\times$ grandiflorum pot ('Madras' and 'Justyna') and cut ('Zembla White') varieties with Pentakeep-V. Best results were obtained if $0.05 \%$ was used and fertilizing was completed with plus $50 \%$ fertilizer. Krzyminska (2007) examined the effect of Pentakeep-V on the bulb production and quality of Allium christophii, Tulipa 'Lucky Strike', Lilium 'Star Gazer', and Gladiolus 'White Friendship'. He found that the $0.05 \%$ treatment increased the weight of the bulbs comparing to the control. $0.03 \%$ solution increased the number of bulblets by tulip. $0.05 \%$ treatment gave the best results by Lilium and both dilution was effective by Gladiolus.

\section{Material and methods}

The research was carried on in the Feldhoffer Co., Tordas. The plant material was newly re-rooted, potted one rosette shoots in $9 \mathrm{~cm}$ pots of Saintpaulia ionantha Optima 'Chico' (blue-white curly) and '102' (pink-white curly) varieties. Based on the recommendation of the producer company and the previous results nine treatments were tested as follows:

- $0.3 \mathrm{ml} / \mathrm{l}$ dilution, irrigating, with basic fertilizer (3IB)

- $0.3 \mathrm{ml} / \mathrm{l}$ dilution, irrigating, with $30 \%$ long lasting fertilizer (3IF)

- $0.3 \mathrm{ml} / \mathrm{l}$ dilution, leaf spraying with basic fertilizer (3SB)

- $0.3 \mathrm{ml} / \mathrm{l}$ dilution, leaf spraying, with $30 \%$ long lasting fertilizer (3SF) 
- $\quad 0.5 \mathrm{ml} / \mathrm{l}$ dilution, irrigating, with basic fertilizer (5IB)

- $0.5 \mathrm{ml} / \mathrm{l}$ dilution, irrigating, with $30 \%$ long lasting fertilizer $(5 \mathrm{IF})$

- $0.5 \mathrm{ml} / \mathrm{l}$ dilution, leaf spraying with basic fertilizer (5SB)

- $0.5 \mathrm{ml} / \mathrm{l}$ dilution, leaf spraying, with $30 \%$ long lasting fertilizer $(5 \mathrm{SF})$

- control (C)

Leaves were treated with hand sprayer, each plant obtained $5 \mathrm{ml}$ solution. With irrigation $20 \mathrm{ml}$ solution was added to each pot. According to the recommendation of the producer company 30\% plus Osmocote Exact long lasting fertilizer was added to the half of the treatments by both concentrations and treating methods. Control plants were sprayed with tap water.

All the other culture conditions (temperature, light intensity, water supply, air vapour, soil mixture and basic fertilizing) were the same as the whole plant stock in the glasshouse of the company.

24 plant/treatment were examined during the experiment. Treatments and measurements were carried out fortnightly since $28^{\text {th }}$ November 2008 till $6^{\text {th }}$ February 2009. During the evaluation the diameter of leaf rosette, number of leaves, leaf surface, number of flower stems, number of flower buds and flowers, diameter of flowers were measured. In the end of the experiment we determined the fresh and dry weight of 3 plants/treatments and the chlorophyll content of the leaves (Arnon, 1949). Data were evaluated with RopStat statistical program (Vargha, 2007).

\section{Results and Discussion}

\section{The effect of ALA on the chlorophyll content}

The chlorophyll content was determined from average sample of three plants per group (Fig. 1.). All treated groups had higher chlorophyll content than control. Highest level was measured by $3 \mathrm{SB}$ treatment. The chlorophyll content of 3SB and 3SF was significantly higher than the C, 3IB, 5IF and 5SB groups. We have no data for 5SF because the glass tube was broken before the spectrophotometrical measurement. The plants of both fertilizing groups had higher chlorophyll level than the control. Among the ways of treatment spraying, among the concentrations $0.3 \mathrm{ml} / \mathrm{l}$ ALA promoted significantly higher chlorophyll level in the leaves comparing to the control.

\section{The effect of ALA on plant growth and development}

The leaf number of treatments can be seen on Fig. 2. Considering the standard deviation, by $99 \%$ significant level the leaf number of 5IB treatment was lower comparing to the $\mathrm{C}$, $3 \mathrm{IB}, 5 \mathrm{IF}$ and $3 \mathrm{SF}$ treatments. In growing practice this difference (less than 3 leaves) is not interesting, as the decrease doesn't damage the ornamental effect. Furthermore the plant decorates with the flowers.

The average leaf rosette diameter was wider by all treatments comparing to the control, excepting 3IF group. But, considering the standard deviation, by $95 \%$ significant level only among $3 \mathrm{SB}$ and $5 \mathrm{SF}$ groups could be pointed out significant difference (Fig. 3.). The leaf rosette diameter was a bit smaller if plants obtained plus fertilizer together with ALA treatment comparing to those which got only basic amount of fertilizer. This result was strengthened statistically on $90 \%$ significant level. The way of treatment and the two concentrations didn't affect significant difference in this aspect.

The leaf surface values can be seen on Fig. 4. The average leaf surface of 3SB group was significantly bigger comparing to the groups of control, 3IB, 5IF and 5SF by $99 \%$ significant level. The way of treatment, the concentration and the amount of fertilizer alone hadn't effect on the leaf size. It can be concluded that spraying with ALA $0.3 \mathrm{ml} / \mathrm{l}$ concentration and basic fertilizing have synergetic effect on the leaf size.

\section{The effect of Pentakeep-V on flowering}

Considering the flower bud number significantly less number of flower buds developed on the control and 5SF groups than on the 3IB, 5IB and 5SB groups by $99 \%$ significant level. Moreover less flower bud initiated on the plants of 3SF group comparing to 3IB group. By $95 \%$ significant level less flower buds developed on the plants of 5IF and 3SB than on 3IB group (Fig. 5.). If comparing the way of treatment alone, concentrations and amount of fertilizer in all cases much less number of flower buds developed by control group than by the other treatments. The plants obtaining plus 30\% Osmocote differed significantly less flower buds than other groups by $99 \%$ significant level. The groups treated with ALA by irrigation formed more buds than those treated with ALA by spraying at $95 \%$ significant level. There wasn't difference between the effect of two concentrations. The significant differences in flower bud number between the groups treated with ALA or not can be considered mentionable result. This result is rather important according to horticultural practical aspect, as the number of flower buds determines the flowering intensity.

The number of flowers showed similar view to the number of buds (Fig.6.). Significantly less flowers appeared on the plants of control and 3SF groups comparing to the groups of 3IB, 5IB, 3SB and 5SB by $99 \%$ significant level. Plants of group 5SB developed more flowers than 5SF and 5IB as well. Those groups which obtained ALA and basic fertilizer formed much more flowers than those which obtained plus $30 \%$ fertilizer together with ALA by $99 \%$ significant level. There wasn't mentioning difference between the effect of treatment methods or concentrations used. The difference between the groups treated with ALA and control is important in practical aspect as well.

In the number of flower stem we couldn't register so big difference among the given groups like in the number of flower buds or flowers. The use of $0.3 \mathrm{ml} / \mathrm{l}$ concentration resulted significantly more flower stem than $0.5 \mathrm{ml} / \mathrm{l}$. The way of treatment or amount of fertilizer hadn't significant effect on the number of flower stem.

Considering the flower diameter there wasn't significant difference among the groups. the way of treatment, concent- 


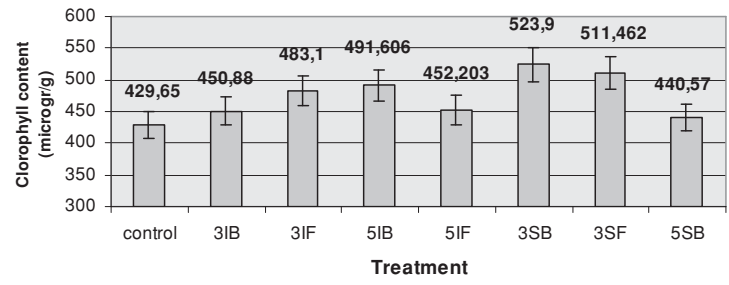

Figure 1. The effect of treatments on chlorophyll content of the leaves of Saintpaulia ionantha $\left(9^{\text {th }}\right.$ March 2009)

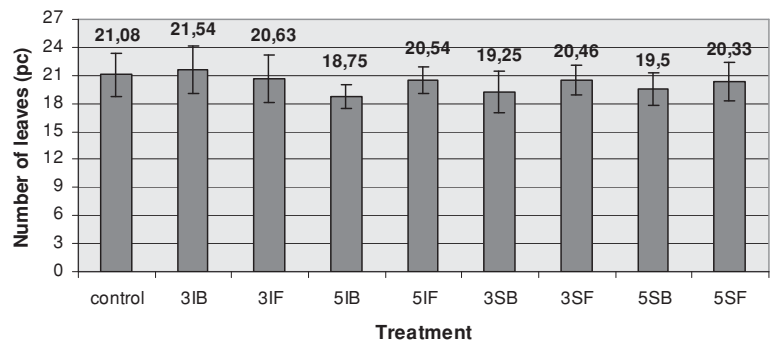

Figure 2. The effect of treatments on the number of leaves of Saintpaulia ionantha $\left(6^{\text {th }}\right.$ February 2009

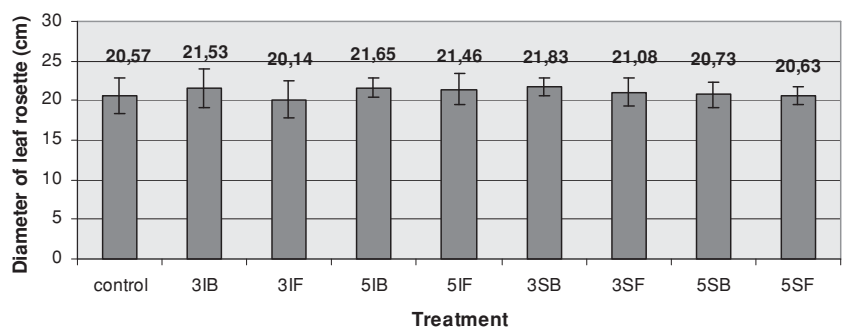

Figure 3. The effect of treatments on leaf rosette diameter of Saintpaulia ionantha $\left(6^{\text {th }}\right.$ February 2009)

ration used nor the amount of fertilizer had any effect on the flower size.

Moreover the most striking difference among the groups was shortening the time till flowering. As Fig. 7 shows the groups of 3IB, 5IB, 3SB and 5SB flowered much earlier than other groups. Consequently the flowering time wasn't affected by the concentrations or ways of treatment but strongly affected by the quantity of fertilizer used combined with ALA treatment. The plant groups obtaining plus 30\% fertilizer with ALA treatment started to flower much later than those which obtained ALA treatment alone. But, even the over-fertilized groups developed more flowers than the control plants. The groups obtaining ALA alone began to flower on $6^{\text {th }}$ February comparing to the control group, that didn't begin to flower even at the end of the experiment, $20^{\text {th }}$ February. Based on these results we can conclude that with the use of ALA as adding fertilizer Saintpaulia ionantha begins to flower minimum two weeks earlier therefore the cultivation period becomes shorter. In the aspect of practice it is important result, and correlates with the results of Cosmo Seiwa Agriculture Co., Ltd. with Primula.

\section{The effect of Pentakeep-V on fresh and dry weight}

In the case of fresh weight we found more than $10 \mathrm{~g}$ differences among the treatments but, considering the standard deviation the results couldn't be proved statistically.

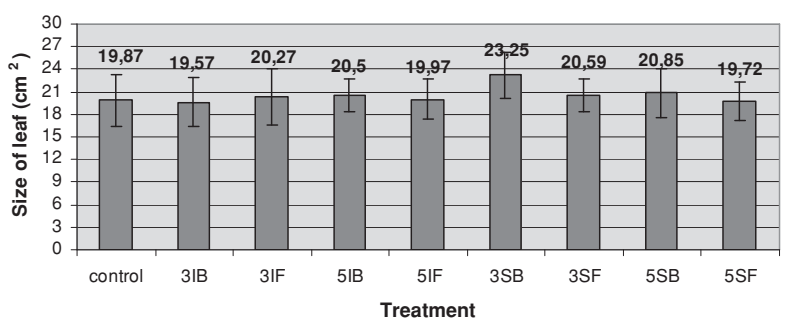

Figure 4. The effect of treatments on leaf size of Saintpaulia ionantha $\left(6^{\text {th }}\right.$ February 2009)

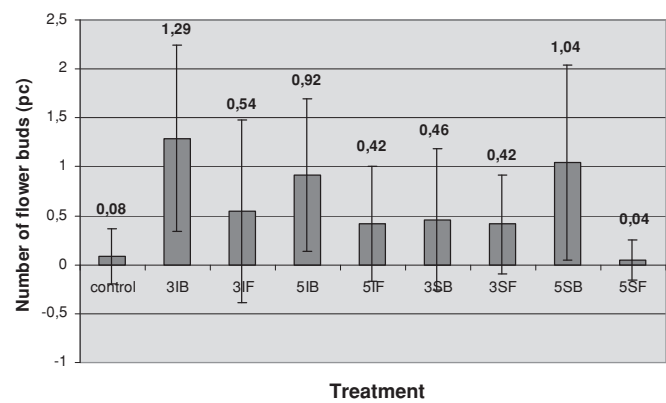

Figure 5. The effect of treatments on number of flower buds of Saintpaulia ionantha ( $6^{\text {th }}$ February 2009)

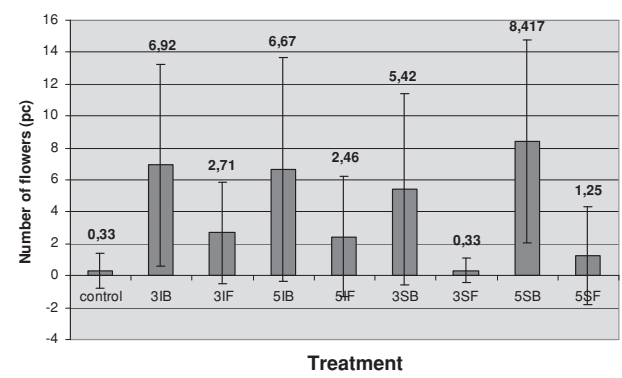

Figure 6. The effect of treatments on number of flowers of Saintpaulia ionantha $\left(20^{\text {th }}\right.$ February 2009)

The groups obtaining ALA plus 30\% fertilizer developed more fresh weight independently from the way of treatment or concentration used comparing to the groups treated with ALA alone. Absolutely no difference was observed among the treatments in the case of dry weight.

\section{Summary}

Our results strengthen the report of Hotta et al. (1997) and Bingshan et al. (1998) as the treatment with ALA grows the chlorophyll content in the leaves. In the case of Saintpaulia ionantha this rate was $15-20 \%$ which can result the growth of leaf surface. Similarly the higher chlorophyll content could result higher assimilating capacity which results earlier flower formation. This fact gives the possibility of shortening the culture period. Among the fertilizing treatments $0.3 \mathrm{mg} / 1$ concentration gave best results, as among the spraying treatments $0.5 \mathrm{ml} / 1$ was the most successful.

Till the close of our experiments our results didn't support that the plants that have grown assimilating capacity can utilize more fertilizer. The effect of extra fertilizer by 

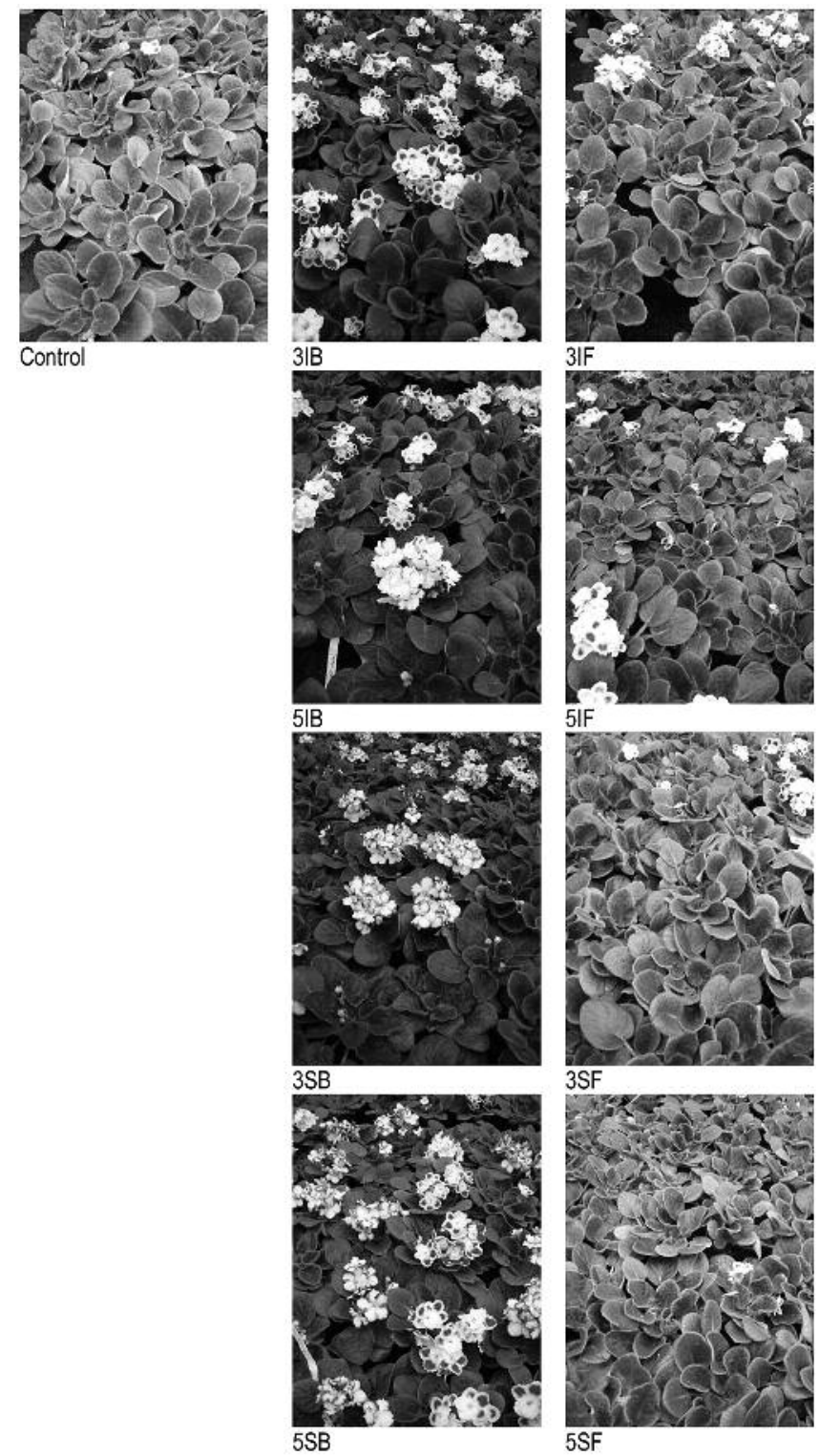

5SF

Figure 7. The effect of treatments on flowering of Saintpaulia ionantha (20 ${ }^{\text {th }}$ February 2009)

both irrigating and spraying treatments resulted higher leaf weight but didn't result more flowers. The plus fertilizer had positive effect on leaf fresh weight but, none of the treatments had any effect on the dry weight.

Summarizing treatment with ALA significantly shortened the cultivation period of Saintpaulia ionantha. Plants treated with ALA became ready for market more than two weeks earlier than control plants and those obtained plus $30 \%$ long lasting fertilizer. This result is in correlation with the result obtained with Primula varieties by the manufacturer. In agreement with the manufacturer in some cases ALA had positive effect on the quantity and size of leaf rosette but, in practice this effect hasn't great importance. Moreover ALA increased the chlorophyll content in the leaves. Following by economical calculations Pentakeep-V (ALA) can be offered to growers for shortening cultivation time in Saintpaulia ionantha.

\section{References}

Arnon, D.I. (1949): Copper enzymes in isolated chloroplasts. Polyphenoloxidase in Beta vulgaris. Plant Physiology, 24. (1): 1-15.

Bingshan, L., Hotta, Y., Q. Yinglan, Z. Jinsong, T. Tanaka, Y. Takeuchi, M. Konnai (1998): Effects of 5-Aminolevulinic Acid ont he growth and Ripening of Wheat. J. Pesticide Sci., 23: 300-303.

Cosmo Seiwa Agriculture Co., Ltd.a The effect of Pentakeep-V to flowers. htpp://pentakeep-world.com/english/pentakeep_v/pdf/ caseofuse01.pdf

Hamrick, D. (2003): Crop Culture A-Z. In: Ball Redbook 17th Edition, Volume 2. Crop Production. Illinois USA. Publishing. p. 253-256., 625-627.

Hotta, Y., T. Tanaka, H. Takaoka, Y. Takeuchi, M. Konnai (1997): New Physiological Effects of 5-Aminolevulinic Acid in Plants: The Increase of Photosynthesis, Chlorophyll Content and Plant Growth. Biosci. Biotech. Biochem., 61. (12): 2025-2028.

Hotta, Y., T. Tanaka, H. Takaoka, Y. Takeuchi, M. Konnai (1997): Promotive effects of 5-aminolevulinic acid ont he yield of several crops. Plant Growth Regulation, 22: 109-114.

Kosáry J. (2008): [Biochemistry of storage. 2. Food biochemistry] A tárolás biokémiája 2. Élelmiszer-biokémia. Budapesti Corvinus Egyetem, Élelmiszertudományi Kar Alkalmazott Kémia Tanszék, Internetes kiadás, p. 14-16. http://www.uni-corvinus.hu/fileadmin/ user_upload/hu/tanszekek/elelmiszertudomanyi/alkalmazottkemia/seg edanyag_ppt_pdf/TarbioElbio2008.DOC

Krzyminska, A. (2007): Influence of Pentakeep-V on yield and quality of tulip, allium, lilium bulbs and gladiolus corms. http://www.agroniwa.pl/files/07_praha_2007_dr_krzyminska.pdf

Murányi A. (2006): Pentakeep- $V$, an exceptional plant conditioner. Pentakeep-V International Scientific Workshop. 10-11. December 2006. Budapest htpp://www.agroniwa.pl/files/budapeszt_2006_ dr_muranyi.pdf

Nishihara, E., K. Kondo, M.M. Parvez, K. K. Takahashi, K. Watanabe, K. Tanaka (2003): Role of 5-aminolevulinic acid (ALA) on active oxygen-scavenging system in $\mathrm{NaCl}$-treated spinach (Spinacia oleracea). J. Plant Physiol., 160: 1085-1091.

Nowak, J. (2006): The effect of Pentakeep-V on growth and flowering of chrysanthemum (Chrysanthemum x grandiflorum (Ramat.) Kitam.) htpp://www.agroniwa.pl/files/budapeszt_2006_prof._nowak.pdf

Pásztor, F. (2008): [The effect of irrigation and Pentakeep.V ont he water circulation of maize and sorghum] Az öntözés és a Pentakeep- $\mathrm{V}$ lombtrágya hatása a kukorica és a cirok vízforgalmára. Tudományos Diákköri Konferencia. 2008. december 16. Debreceni Egyetem Agrárés Müszaki Tudományok Centruma. p. 80. htp://www1.unideb.hu/media/871_48.pdf

Vargha, A. (2007): [The statistical system of RopStat] A RopStat statisztikai menürendszere. http://www.ropstat.com/download/rop _hun_stat.doc

Vágújfalvi, D. (2007): [Porfirines] Porfirinek. In: Láng F. (ed./szerk.): [Plant Physiology, The Metabolism of Plants II.] Növényélettan, A növényi anyagcsere II.. Budapest. ELTE Eötvös Kiadó, p. 584-587.

Watanabe, K., T. Tanaka, Y. Hotta, H. Kuramochi, Y. Takeuchi (2000): Improving salt tolerance of cotton seedlings with 5aminolevulinic acid. Plant Growth Regulation, 32: 99-103.

Yoshida, R., Ohta, E., Iwai, K., Tanaka, T., Okada, H., (2005): Effects of liquid fertilizer containing 5-aminolevulinic acid on thickening growth in tulip bulbs., p. 91-94. http://www.pgrsa.org/ 2005_Proceedings/papers/031.pdf 